\title{
One material transfer agreement to rule them all? A call for revising South Africa's new standard material transfer agreement
}

\author{
Donrich Thaldar (1) ${ }^{1 凶}$
}

In 2018, the South African Minister of Health gazetted a material transfer agreement (SA MTA) that must be used as a framework whenever a researcher based in South Africa is involved in the transfer of human biological material. The SA MTA therefore impacts not only on the South African research community, but also its international research partners. The SA MTA has been portrayed in a positive light by Labuschaigne et al. in a recent article. By contrast, in this present article, the position taken is that the SA MTA is deeply problematic, and it is argued that Labuschaigne et al. have erred with regard to three key propositions of their account of the SA MTA. The first proposition, namely that a Health Research Ethics Committee should be a party to a material transfer agreement, as contemplated in the SA MTA, is shown to be unfeasible. Similarly, the second proposition, namely that under the SA MTA a research participant retains proprietary rights in donated human biological material, is shown to be legally untenable. The third proposition, namely that the arbitration option in the SA MTA (which allows parties to opt out of the jurisdiction of South African courts) is both necessary and adequate, is shown to be false. Not only is the claim that the arbitration option is required by international collaborators contradicted by Labuschaigne et al.'s own example, but the present SA MTA's dispute resolution provisions are shown to be inadequate. In this light, a more appropriate solution in respect of dispute resolution is proposed. In the interest of both the South African research community and their international research partners, the South African Minister of Health is called upon to engage in open public consultation on the SA MTA and to fundamentally revise it as a matter of urgency. 


\section{Introduction}

W

hile the sharing of human biological material between collaborating researchers all over the globe is important to scientific progress, it is not without ethical and legal challenges. Recently, a furore erupted around the Sanger Institute, a well-known genome research centre in the United Kingdom, based on allegations that it commercialised a gene chip without proper legal agreements with either the providers of the human biological material that was used in developing the gene chip-African universities-or with the donors of the human biological material, namely African research participants (Stokstad, 2019). One of these universities, the University of Stellenbosch in South Africa, demanded that Sanger return samples (Stokstad, 2019). This incident demonstrates the sensitive nature of international transfer of human biological material, and underscores the necessity of having fair and well drafted material transfer agreements (MTAs) in place.

MTAs typically have two parties, the provider of the biological material and the recipient thereof, and set out the rights and duties of each with relation to a variety of topics, ranging from the research purpose for which the material may be used to how disputes between the parties will be resolved. Like with any other type of agreement, MTAs can be custom-developed and the terms negotiated for each transaction. However, given the frequent nature of the transfer of human biological material between research institutes worldwide, standard MTAs have been developed. Well-known examples are the Uniform Biological Material Transfer Agreement (UB MTA) developed by the National Institutes of Health (NIH) in collaboration with research institutions, and the Standard Material Transfer Agreement 2 (SMTA 2) used by the World Health Organisation (WHO).

Around the same time that the allegations against the Sanger Institute were made, in 2018-in an apparent attempt to provide guidance to the South African research community and its international partners-the South African Minister of Health gazetted the 'Material Transfer Agreement of Human Biological Materials' (SA MTA). Whenever parties transfer human biological material for the purposes of health research out of, into, or within South Africa, they are legally compelled to use the SA MTA as a framework for their own MTAs. This makes South Africa the only country to have a legally enforced national standard MTA. What was the motive behind this legislative intervention?

The academic literature suggests that the Sanger incident was not an isolated event. As noted by Nienaber (2011), there is a history of allegations of unethical or illegal conduct by health researchers regarding the use of South African-and more generally African-human biological material. Furthermore, Nienaber highlights that there is a movement against 'research imperialism' $-\mathrm{a}$ term that refers to situations where researchers in the richer countries undertake research in poorer countries, but do not share the benefits of that research in a fair way with research participants and scientific collaborators in the poorer countries. Given this movement against research imperialism, it is unsurprising that there is a perception, noted by Mahomed and Labuschaigne (2019), that MTAs used in the international sphere fail to adequately address legal concerns specific to South Africa. Mahomed and Labuschaigne also highlight that many cultures in South Africa attach particular significance to human biological material. This clearly adds oil to the fire. It is against this background that the promulgation of the SA MTA must be understood. However, whether the SA MTA in its current form will be an effective means to counter research imperialism is far from certain.

In a recent article, Labuschaigne et al. (2019) unpack the SA MTA and present it in a positive light. They state that
The SA MTA is founded on the principles of justice, fairness and dignity, in line with the principles of the World Medical Association's Declaration of Taipei on Ethical Considerations Regarding Health Databases and Biobanks and the Council for International Association of Medical Scientists guidelines, and in keeping with international best practices.

By contrast, I believe that the SA MTA is an overhasty regulatory attempt that is flawed in theory and likely to be inadequate in practice. Elsewhere, my co-authors and I analysed the SA MTA's substantive fit with extant law, its practicality and its clarity, and highlighted numerous problematic issues (Thaldar et al., 2020). The analysis in Thaldar et al. (2020) forms the basis for the critique of the SA MTA in this article. However, the problematic nature of the SA MTA extends to the way in which it was interpreted and defended by Labuschaigne et al. In this present article, the main focus is on three key propositions in Labuschaigne et al.'s article. These three key propositions are: (a) a Health Research Ethics Committee (HREC) should be a party to a material transfer agreement, as contemplated in the SA MTA; (b) under the SA MTA a research participant retains proprietary rights in donated human biological material; and (c) the arbitration option in the SA MTA (which allows parties to opt out of the jurisdiction of South African courts) is both necessary and adequate.

\section{Analysis}

The role of HRECs. The South African National Health Act (NHA) provides that all proposed health research studies must be approved by a HREC that is registered as such with the National Health Research Ethics Council. HRECs have an ethical oversight function, with a particular focus on protecting the interests of research participants (Department of Health, 2015).

The SA MTA (in paragraph 2.14 and in the recital) requires that a HREC must be a party to the MTA. The reason for this requirement is not clear. If the reason was to place HRECs in a better position to impact the terms and implementation of a MTA, it would be misconceived, as HRECs' oversight function is compromised by being made part of an object of their oversightone can hardly fulfil an oversight role over something that one is part of. Apart from being counter-productive, the requirement that a HREC must be part of a MTA is also not feasible: A basic rule of South African law is that only an entity with juristic personhood has the legal capacity to enter into agreements (such as a MTA). The question is therefore: Are HRECs juristic persons? Labuschaigne et al. recognise this question and its implications when they state:

It may be argued that the HREC is not a separate legal entity and hence is unable to enter into such an agreement.

However, instead of pursuing an answer to this vital question and confronting the consequences, Labuschaigne et al. subtly rephrase the question of whether HRECs can as a matter of law be parties to MTAs, to whether HRECs should as a matter of policy be parties to MTAs. This simply avoids the issue.

According to the South African National Health Research Ethics Council's website, there are currently 46 HRECs registered as such with the Council. It is clear from the description of these HRECs that they are internal committees of research institutions -bar one HREC that is a private company. Accordingly, only this one HREC is a juristic person and hence able to be a party to an agreement. This is the reality that Labuschaigne et al. avoided engaging with. Accordingly, being a party to a MTA is a legal impossibility for all but one of the HRECs in South Africa. It 
follows that the requirement in the SA MTA that a HREC must be a party to the MTA is clearly not feasible. The Minister should remedy this situation by amending the SA MTA to remove all references to HRECs as parties to MTAs.

The locus of legal rights in human biological material. In South African law, proprietary rights in human biological material that is donated for research are governed by the Regulations regarding the General Control of Human Bodies (the General Control Regulations). Regulation 26 provides that a person to whom human biological material is legally donated for the purposes of research, and who uses it for research, acquires exclusive rights in respect thereof. This means that no other person can hold any rights in such human biological material. However, the SA MTA (in paragraph 3.3) provides that the 'the donor remains the owner of the material until such materials are destroyed'. Ownership-in its general, unencumbered sense-is the most comprehensive legal right that a legal subject can have in a legal object. Such a general, unencumbered interpretation of ownership would therefore be in conflict with the exclusive rights provision of the General Control Regulations.

Labuschaigne et al. however believe that the SA MTA's ownership provision is 'in line with' the General Control Regulations. In support of this view, they rely on regulation 7 of the General Control Regulations which states that human biological material may only be donated for a purpose provided for in the NHA (such as research), and that the person to whom human biological material has been donated (such as a biobank) may use it only for that said purpose. Labuschaigne et al. interpret regulation 7 as giving the donor 'proprietary control' over the donation, in the sense that the donation may not be used for purposes other than those provided for in the NHA. In doing so, however, Labuschaigne et al. read in things that simply are not there. The fact that regulation 7 limits the ways in which donated human biological material may be used, in no way implies that the donor retains any rights. Consider the following everyday example: A donates her car to B. The law places limits on the way in which cars may be used-for instance, one may not use a car to drive over the speed limit, or intentionally cause damage to property. However, none of the myriad of legal limits on the way in which cars may be used can be construed to imply that A (the donor) retains any rights or 'proprietary control' over the car that she donated to B. Accordingly, Labuschaigne et al.'s view that the SA MTA's ownership provision is 'in line with' the General Control Regulations is legally unsound.

The only way to reconcile the apparently conflicting provisions of the SA MTA and the General Control Regulations, is to interpret the ownership provision in the SA MTA as completely encumbered ownership-ownership in name only, entailing no enforceable rights in the human biological material. This, of course, does not exclude the possibility that the research participant can have other rights that can be enforced against the research institution and specific third parties, such as the recipient in terms of a MTA. These rights can be established through, inter alia, statute or contract. For instance, the donation agreement between the research participant and the research institution can specify that the research participant has the right to withdraw from the study at any stage and have the donated material destroyed.

The intention behind the provision in the SA MTA that the research participant 'remains the owner' of the material could have been to strengthen the research participant's rights and negotiating position in benefit-sharing negotiations. However, it is doubtful whether ownership in name only will accomplish any of these purposes. To the contrary, the SA MTA's ownership provision may place research participants under the wrong impression that they have more rights than they actually have. Therefore, the ownership provision in the SA MTA should be struck out, as it only muddies the legal water, and it in no way contributes to protecting research participants.

The practical implications of opting for international arbitration. The dispute resolution provisions of any agreement are always of the utmost importance: If dispute resolution provisions make it unaffordable for one party to enforce its rights in terms of the agreement, it effectively gives the other party free rein to do as it pleases. Having a contractual right only means something if one has the means to enforce it. For instance, how many (if any) South African research institutions have the means to be involved in protracted litigation abroad? The answer, I suggest, is very few, if any. Against this background, the SA MTA provides that if a dispute cannot be resolved amicably, any party can initiate litigation-in which case the dispute must be heard in a South African court according to South African law. However, the SA MTA also provides that the parties can opt out of litigation by agreeing to resolve the dispute by arbitration. If the parties opt for arbitration, the SA MTA does not clearly state whether the arbitration must take place in South Africa, or whether South African law must still apply. The danger inherent in this arbitration option is that South African parties may agree to arbitration using non-South African rules of procedure, non-South African substantive law, and at a non-South African venue-all potentially making such arbitration unaffordable for the South African parties.

Labuschaigne et al. appear to accept that an arbitration agreement can indeed change the legal system and place of adjudication to a non-South African jurisdiction. They recognise that arbitration abroad may be unaffordable for South African parties, and state that 'it may be argued' that arbitration proceedings weaken the dispute resolution process 'somewhat', in that arbitration can occur outside South Africa. However, Labuschaigne et al. nevertheless take the position that the arbitration option is necessary, because it is in keeping with standards prescribed by Western counterparts'. In support of their argument, Labuschaigne et al. use the UK Biobank as an example, which 'specifically outlines that any unresolved dispute is to be mediated [my emphasis] at the London Court of International Arbitration' (LCIA). However, for reasons discussed below, Labuschaigne et al.'s example of the UK Biobank contradicts their own argument.

Firstly, it is necessary to distinguish between arbitration and mediation. While both are types of alternative dispute resolution, arbitration and mediation are not the same-in fact they are alternatives to one another. If Labuschaigne et al. are correct that the UK Biobank in fact requires that any unresolved dispute be mediated, such mediation will not be allowed by the SA MTA, as it only makes provision for arbitration as an alternative to litigation, and not mediation. Secondly, it is not correct (as Labuschaigne et al. suggest) that the UK Biobank 'specifically outlines that any unresolved dispute is to be mediated' [my emphasis]. In fact, the UK Biobank's MTA provides (in paragraph 17.3) that in the event that a dispute remains unresolved for 10 business days 'either party may initiate nonbinding mediation' [my emphasis]. If neither party elects to initiate non-binding mediation, or if the eventual non-binding mediation outcome is not acceptable to a party, or if a party seeks interim relief during non-binding mediation, the UK Biobank's MTA provides (in paragraphs 17.4 and 18.7) that such a party can initiate litigation in the English courts. Accordingly, Labuschaigne et al.'s own example fails to support their argument. 
On a technical note: In their reference to the UK Biobank's MTA, Labuschaigne et al. state that they refer to version 1.3 of the said MTA, but-confusingly-the hyperlink in their reference is in fact to the current version, version 1.4, dated 17 May 2017 (UK Biobank, 2017). Also, the year of publication stated in the reference is 2017, which corresponds with version 1.4, not version 1.3 , which is in fact dated from 2015 (UK Biobank, 2015). In any event, the relevant terms of the UK Biobank's MTA did not change between versions 1.3 and 1.4. Therefore, the error in Labuschaigne et al.'s referencing does not change the above analysis.

However, let us assume arguendo that there is a biobank somewhere in the world that requires that any unresolved dispute is to be arbitrated at the LCIA. According to LCIA's own statistics (London Court of International Arbitration, no date), the average LCIA arbitration costs US\$97,000 (about ZAR1.63m) only for the tribunal fees (such as the arbitrator's fees) and administrative fees (fees charged by the LCIA secretariat). In contrast, a judge sitting in a South African court, the courtroom, and the administration of the court in South Africa is paid for by the state-and it costs the parties nothing. To these tribunal and administrative fees of arbitration at LCIA, must still be added the legal fees charged by each party's respective legal representatives (presumably British lawyers), who prosecuted the arbitration on their clients' behalf.

In the light of these facts, LCIA arbitration seems less than appealing from the perspective of a South African party to a MTA. In addition to this, one might ask how South African research participants will enforce their rights against a nonSouth African recipient of human biological material if disputes are adjudicated in London? Such an arrangement deprives South African research participants of the opportunity to enforce their rights in their own country's courts. Although the title of Labuschaigne et al.'s article refers to protecting research participants, Labuschaigne et al. do not consider this crucial question.

In light of this, the most practical and just solution would be to require that whenever the provider of human biological material is located in South Africa, South African law must apply and the South African courts must have jurisdiction, except if the parties agree to arbitration according to South African law to take place in South Africa. A measure of flexibility can be built in by making it possible for the Minister of Health to grant exemptions upon good reasons provided. However, in cases where the provider is in a non-South African jurisdiction and the receiver is in South Africa, the SA MTA should not impose the legal system or the jurisdiction. This is an even-handed approach, which will provide more realistic protection for South African research participants.

\section{Conclusions}

In Labuschaigne et al.'s assessment, the SA MTA is a fitting example of how South Africa safeguards research participants and protects dignity, fairness and justice. I suggest that this is an over optimistic assessment. Setting unfeasible requirements, such as making HRECs parties to MTAs, is a recipe for uncertainty and embarrassment-not for justice. Promising ownership in donated material to research participants when such ownership is actually ownership in name only is a recipe for confusion and disappointment, not for protecting dignity. What is more, providing for an arbitration option that will most likely move disputes beyond the jurisdiction of South African courts and South African law is a recipe for disempowerment, not for protecting dignity-and certainly not for safeguarding the interests of South African research participants.

The South African research community and its international research partners can certainly benefit from a framework MTA that can serve as a guide for good practice. However, the SA MTA in its current form detracts from-rather than promotes - good practice. Moreover, the South African research community and its international research partners can benefit from clear, correct, and critical analysis of the SA MTA, not undue praise. I call on the South African Minister of Health to engage in open public consultation on the SA MTA with a view to fundamentally revising it, and to do so as a matter of urgency.

Received: 2 April 2020; Accepted: 8 September 2020; Published online: 24 September 2020

\section{References}

Department of Health, South Africa (2015) Ethics in health research: prin ciples, processes and structures, 2nd edn. Department of Health, Pretoria

Labuschaigne M, Mahomed S, Dhai A et al. (2019) Protecting participants in health research: the South African Material Transfer Agreement. S Af Med J 109(5):353-356. https://doi.org/10.7196/SAMJ.2019.v109i5.13803

London Court of International Arbitration, Costs and duration: 2013-2016 (no date) https://www.international-arbitration-attorney.com/wp-content/uploads/2018/ 07/LCIA-Costs-and-Duration-Statistics.pdf. Accessed 10 June 2020

Mahomed S, Labuschaigne M (2019) The role of research ethics committees in South Africa when human biological materials are transferred between institutions. S Afr J Bioeth Law 12:84-87. https://doi.org/10.7196/SAJBL.2019.v12i2.685

Material Transfer Agreement of Human Biological Materials, South Africa. Government Notice 719, Government Gazette 41781 of 20 July 2018. https:// www.gov.za/sites/default/files/gcis_document/201808/41781gon719.pdf. Accessed 10 June 2020

National Health Act 61 of 2003, South Africa. https://www.gov.za/sites/default/files/ gcis_document/201409/a61-03.pdf. Accessed 10 June 2020

National Health Research Ethics Council, South Africa. List of Human Research Ethics Committees (HRECs) registered with NHREC. http://nhrec.health.gov. za/index.php/extras. Accessed 10 June 2020

Nienaber A (2011) Consent to and authorisation of the export and use of human biological specimens for future research-perspectives from three African countries. Comp Int Law J S Afr 44:225-254. https://www.jstor.org/stable/ 23253098

Regulations regarding the General Control of Human Bodies, Tissues, Blood, Blood Products and Gametes, South Africa. Government Notice R180, Government Gazette 35099 of 2 March 2012. https:/www.gov.za/sites/default/files/ gcis_document/201409/35099rg9699gon180.pdf. Accessed 10 June 2020

Stokstad E (2019) Major UK genetics lab accused of misusing African DNA. Science https://doi.org/10.1126/science.aba0343

Thaldar DW, Botes M, Nienaber A (2020) South Africa's new standard material transfer agreement: proposals for improvement and pointers for implementation. BMC Med Eth 21:85. https://doi.org/10.1186/s12910020-00526-x

UK Biobank (2015). Collaborator's MTA v1.3

UK Biobank (2017). Collaborator's MTA v1.4. http://www.ukbiobank.ac.uk/wpcontent/uploads/2011/03/20170519-Collaborator-MTA-for-website.pdf. Accessed 10 June 2020

\section{Acknowledgements}

The author wishes to thank Christopher Gevers and Judy Parker for helpful comments on this article. All remaining errors remain the author's alone. This research has received University of KwaZulu-Natal, African Health Research Flagship Grant and National Research Foundation Grant 116275

\section{Competing interests}

The author declares no competing interests.

\section{Additional information}

Correspondence and requests for materials should be addressed to D.T

Reprints and permission information is available at http://www.nature.com/reprints

Publisher's note Springer Nature remains neutral with regard to jurisdictional claims in published maps and institutional affiliations. 
(c) (i) Open Access This article is licensed under a Creative Commons Attribution 4.0 International License, which permits use, sharing, adaptation, distribution and reproduction in any medium or format, as long as you give appropriate credit to the original author(s) and the source, provide a link to the Creative Commons license, and indicate if changes were made. The images or other third party material in this article are included in the article's Creative Commons license, unless indicated otherwise in a credit line to the material. If material is not included in the article's Creative Commons license and your intended use is not permitted by statutory regulation or exceeds the permitted use, you will need to obtain permission directly from the copyright holder. To view a copy of this license, visit http://creativecommons.org/ licenses/by/4.0/.

(C) The Author(s) 2020 